УДК 342.553.077.1-056.263:342.722

DOI https://doi.org/10.32837/yuv.v0i3.2191

О. Каплій,

кандидат юридичних наук,

доцент кафедри конституційного та адміністративного права і процесу

Чорноморського національного університету імені Петра Могили

\title{
ЗВЕРНЕННЯ ОСІБ ІЗ ПОРУШЕННЯМ СЛУХУ ДО ОРГАНІВ ПУБЛІЧНОЇ ВЛАДИ ЯК ОСНОВНИЙ ЗАСІБ РЕАЛІЗАЦІЇ ПРАВА НА ІНФОРМАЦІЮ
}

Постановка проблеми. Право направляти індивідуальні чи колективні звернення або особисто звертатися до органів державної влади, органів місцевого самоврядування та посадових і службових осіб цих органів, що зобов'язані розглянути звернення і дати обгрунтовану відповідь у встановлений законом строк, $€$ не лише конституційним правом людини і громадянина, а й основним каналом зв'язку між громадянином і державою, який сприяє вирішенню та реалізації публічною владою та іiі посадовими особами соціально-економічних та інших конституційних прав громадян, ефективному реагуванню на вирішення їх проблемних питань i дотриманню принципів належного управління в державі. Нечуючі люди відчувають труднощі під час реалізації права на звернення, мовний бар'єр $€$ найголовнішою перепоною, тому дистанційний зв'язок 3 використанням додатку «ConnectPRO» або «Cервісу УТОГ» є вкрай важливими задля створення рівних можливостей для осіб з порушенням слуху.

Оцінка стану літератури. В Україні проблемам звернення громадян достатньої уваги довгий час не приділялося. Дослідженню проблеми, яка була відзначені у статті, не приділяється достатньої уваги на науковому рівні, законодавством України не врегульовано механізм надання інформаційних послуг жестомовним особам.
Мета дослідження - проаналізувати звернення осіб з порушенням слуху до органів публічної влади як основний засіб реалізації права на інформацію. Для ऑї досягнення необхідно проаналізувати порядок звернення осіб з порушенням слуху до органів публічної влади як основний засіб реалізації права на інформацію та визначити проблеми надання адміністративних послуг під час звернення особам з порушенням слуху на прикладі досвіду м. Миколаєва.

Виклад основного матеріалу. Відповідно до статті 9 Конвенціі про права осіб з інвалідністю Україна, як держава-учасниця, має вживати належних заходів для забезпечення таким особам нарівні з іншими доступу до інформаційних, комунікаційних та інших служб. Так, у Заключних зауваженнях по першочерговій доповіді України у п. 38 Комітет $\mathrm{OOH}$ з прав осіб 3 інвалідністю відзначає обмежену кількість перекладачів жестової мови для користувачів державних послуг [3]. Усупереч особливостям здоров'я, зумовленим порушенням слуху, особи 3 порушенням слуху $є$ рівноправними членами суспільства та наділені правом на включення їх у соціум засобами інклюзії. Вони мають право на створення умов для спілкування з оточенням, зокрема із застосуванням жестової мови $[17$, с. 63$]$.

Слід зауважити, що законодавством України не врегульовано меха- 
нізм надання інформаційних послуг жестомовним особам. 3 метою виконання вимог ст. 34 Конституціï України [5], ст. 302 Цивільного кодексу України [20] деякі державні структури, організації різних форм власності самостійно намагаються допомогти реалізувати право осіб 3 порушенням слуху на надання інформаційних послуг у різних сфеpax нарівні 3 іншими громадянами України. Наприклад, у сервісних центрів міністерства внутрішніх справ забезпечена можливість сурдоперекладу для осіб з інвалідністю. Як показує практика діяльності деяких інклюзивно-привітних сервісів для глухих людей і таких, що недочувають, у Центрах надання адміністративних послуг, такий дистанційний зв'язок і надання послуг жестовою мовою є вкрай важливими.

У ході детального огляду національного законодавства щодо надання адміністративних послуг, в тому числі права на інформацію при зверненні, особам з порушенням слуху виявлено неврегульованість їх надання. Отже, такий стан справ призводить до унеможливлення отримання самостійно даних послуг. Вважаємо за потрібне запровадити використання в усіх органах державної влади та місцевого самоврядування додатку «ConnectPRO» або «Сервісу УТОГ» задля створення рівних можливостей для осіб з порушенням слуху.

Актуальність даного питання пов'язано також з тим, що 25 квітня 2019 р. Верховна Рада України ухвалила закон «Про забезпечення функціонування української мови як державної», у якому вперше закріплено статус української жестової мови та права жестомовних осіб. Так, у ст. 2 зазначається: «Українська жестова мова - це природна візуально-жестова мовна система 3 власною лексико-граматичною структурою, що сформувалася еволюційним шляхом і використовується як основний або один з основних засобів спілку- вання жестомовних осіб, які постійно проживають або впродовж тривалого часу проживали на території України» [12]. Водночас до завдань цього ж Закону віднесено «розвиток української жестової мови як основного або одного з основних засобів спілкування жестомовних осіб. Статус, засади та порядок застосування української жестової мови визначаються законом» [12].

Щодо окремого Закону, то варто відзначити, що 29 жовтня 2019 р. було зареєстровано проект Закону «Про українську жестову мову» № 2340, який 2 лютого 2021 року було включено до порядку денного п'ятої сесії Верховної Ради України [14].

Відповідно до пояснювальної записки завданням проекту Закону $€$ визначення статусу, засад та порядку застосування української жестової мови в Україні, створення необхідних умов, які дають жестомовним особам можливість нарівні 3 іншими реалізовувати всі права й основоположні свободи людини і громадянина у політичній, економічній, соціальній, культурній чи будь-якій іншій сфері [9].

Статтею 6 законопроекту передбачається, що «органи державної влади, органи місцевого самоврядування, державні та комунальні підприємства, установи та організації мають забезпечити жестомовним особам умови для вільного використання ними української жестової мови, а також отримання ними у доступній формі інформації, послуг, зокрема, шляхом надання послуг перекладу українською жестовою мовою або шляхом розумного пристосування чи застосування універсального дизайну, що дозволяє передати весь обсяг комунікації, що відбувається засобами словесного мовлення» [15].

Таким чином, щоб реалізувати закріплене та гарантоване Конституцією України право на звернення, особа може звернутися 3 метою висловленням поради, рекомендаціі щодо діяльності відповідних орга- 
нів з пропозицією (зауваженням), із проханням про сприяння реалізаціі закріплених Конституцією та чинним законодавством іiі прав та інтересів із заявою (клопотанням) чи у разі поновлення прав та законних інтересів, зі скаргою до відповідних органів державної влади, органів місцевого самоврядування, підприємств, установ, організацій незалежно від форм власності шляхом письмової або усної форми.

Письмове звернення, зокрема, має містити підпис заявника і може надсилатись поштою, передаватись до відповідного органу або може бути надіслане з використанням мережі Інтернет [13]. Проте практика застосування цих норм, які б мали полегшити комунікацію з державою, викликає чимало запитань. Щодо усного звернення, то положення вказаного Закону України не передбачають залучення перекладача української жестової мови. Оскільки письмове звернення має містити підпис заявника, то це означає, що електронне звернення має бути надіслано власноруч або надруковано на комп'ютері та роздруковане, а потім скановане, що потребує наявності додаткової комп'ютерної техніки, зокрема принтера та сканера. По суті, механізм електронного звернення не спрощує процедуру подання звернень особами з інвалідністю до відповідних суб'єктів.

Погоджуємось, що місцеві органи влади та органи місцевого самоврядування залишаються для осіб з інвалідністю інформаційно недоступними. Не надаються послуги перекладача жестової мови, адже у штатному розписі жодного державного органу не передбачено посади фахівця перекладу жестової мови. За нашими спостереженнями та при спілкуванні 3 представниками Миколаївського осередку «УТОГ», лише протягом 2019-2020 років у Миколаївській області почали зустрічатись поодинокі випадки проходження курсів жестової мови фахівцями Миколаїв- ської обласної державної адміністраціï та ЦНАПів. У звіті громадських об'єднань людей з інвалідність зазначається: «За таких умов особи з інвалідністю вимушені звертатися до цих органів у супроводі. Адже саме супроводжуюча особа заповнює документи. Більше того, комунікація місцевих посадовців часто здійснюється саме з супроводжуючим, а не людиною з інвалідністю, що є неприпустимим» [2, с. 53].

Додатковими способами комунікації з особами 3 інвалідністю із порушенням слуху респонденти називають переписку та дистанційне спілкування з перекладачем у телефонному режимі через відеозв'язок. Лише кілька осіб з порушеннями зору повідомили, що їм зачитувався зміст документа, а в інших випадках допомога не надавалась.

Існує ряд проблем щодо неможливості надання якісних послуг, про які йдеться в звіті громадських об'єднань людей з інвалідністю. Так, із 108 опитаних місцевих посадовців лише 10\% не працювали з особами 3 інвалідністю без участі супроводжуючого, тільки $10 \%$ працівників проходили спеціальне навчання з надання послуг особам 3 інвалідністю. Основними причинами неможливості надати якісні послуги особі з інвалідністю без супроводжуючого, на думку місцевих посадовців, є: брак досвіду та вмінь; незнання жестової мови; недоступність приміщень.

У середньому 20\% опитаних працівників управлінь соціального захисту населення, охорони здоров'я та освіти Вінницької (2 особи iз 15), Житомирської (5 осіб із 15) та Івано-Франківської (3 особи із 17) областей володіють основами жестової мови, тобто знають п'ять і більше жестів. Однак цього недостатньо, i для налагодження належної комунікації необхідним є залучення професійних перекладачів жестової мови в тому числі засобами дистанційного відеозв'язку. 


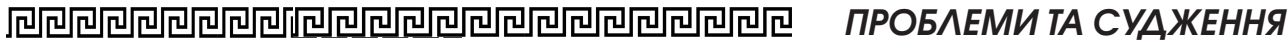

Так, наприклад, у Полтаві ЦНАП співпрацює з УТОГ в налагодженні комунікації з відвідувачами, які мають порушення слуху через дистанційний відеозв'язок з послугою «Сервіс УТОГ»» $[2$, с. 54$]$.

Відповідно до затверджених вимог [11] веб-сайти повинні створюватися максимально доступними та зручними для кожного користувача з використанням керівних принципів доступності веб-контенту (Web Content Accessibility Guidelines (WCAG), розроблених в рамках діяльності Консорціуму Всесвітньої павутини (World Wide Web Consortium) з метою забезпечення єдиного стандарту доступності веб-контенту. В Україні відповідні принципи визначені у ДСТУ ISO/ IEC 40500:2015 «Інформаційні технології. Настанова з доступності веб-контенту W3C (WCAG) 2.0» не нижче рівня АA [6].

Держкомтелерадіо рапортує, що станом на 3 липня 2020 р. повністю виконали вимоги щодо забезпечення доступності інформації для користувачів 3 порушеннями зору та слуху $63,93 \%$ центральних органів влади та $84 \%$ місцевих органів виконавчої влади. Зазначається й низка типових зауважень до не повністю модернізованих сайтів [1].

Вітаючи затвердження міжнародних стандартів доступності сайтів та регулярний моніторинг виконання, ефективність цих дій викликає сумнів, оскільки моніторинги громадськості показують іншу картину. Представники громадянського суспільства розробили додаток «Веб-чекер» - це спеціальна веб-платформа, яка аналізує сайти на їх доступність відповідно до міжнародних стандартів. За допомогою додатка проаналізовано веб-сайт Мінцифри, який, до речі, є в переліку доступних сайтів Держкомтелерадіо, але аналіз виявив декілька сотень недоліків цього веб-сайту в контексті доступності для осіб з інвалідністю.

Використання особами з порушеннями зору спеціальних програм, які адаптують інформацію в доступний формат на персональних комп'ютеpax, забезпечить доступ до інформації в мережі Інтернет лише за умови доступності сайтів. Однак поява на екрані сторінок 3 елементами картинок, які необхідно визначити для здійснення тієї чи іншої операції на сайті, перезавантаженість графічними елементами, відсутність підписів над або під фотографіями суттєво ускладнює роботу з інтернет-ресурсами, зокрема, місцевої влади.

Так, «із п'ятдесяти респондентів та респонденток 3 порушенням слуху з Полтавської області 47 осіб не користуються сайтами, оскільки або не вміють користуватися інтернетом, або заважкий i незрозумілий пошук інформації. Потрібну інформацію такі особи отримують від перекладача жестової мови, працівників Українського товариства глухих (далі - УТОГ) та своїх рідних, друзів» [2, c. 55].

Далі розглянемо порядок надання адміністративних послуг під час реалізації права на звернення осіб з порушенням слуху на прикладі м. Миколаєва.

Центр надання адміністративних послуг (далі - ЦНАП) - «це постійно діючий робочий орган або структурний підрозділ місцевої державної адміністрації або органу місцевого самоврядування, в якому надаються адміністративні послуги через адміністратора шляхом його взаємодії з суб'єктами надання адміністративних послуг. ЦНАПи почали створюватися у 2013 р. на виконання Закону України «Про адміністративні послуги» (далі - ЗУ).

У статті 4 ЗУ зазначається, що «державна політика у сфері надання адміністративних послуг базується на 10 принципах, серед яких є принцип доступності та зручності для суб'єктів звернень» [10]. Не виключено, що суб'єктами звернень можуть виступати люди з певними обмеженнями у спілкуванні - наприклад, люди 
3 порушенням слуху. Адже вони $€$ членами суспільства і теж мають потребу, як і будь-яка людина, в отриманні різного виду адміністративних послуг доступно та зручно.

Доступність відповідно до ст. 9 Конвенції ООН про права осіб з інвалідністю (далі - Конвенція ООН) є можливістю вести незалежний спосіб життя й усебічно брати участь у всіх аспектах життя [4]. Україна, як держава-учасниця, має вживати належних заходів для забезпечення таким особам нарівні 3 іншими доступу до інформаційних, комунікаційних та інших служб.

Україна не так давно ратифікувала Конвенцію. Так, у Заключних зауваженнях по першочерговій доповіді України (далі - Заключні зауваження) у п. 38 Комітет ООН з прав осіб 3 інвалідністю (далі - Комітет) відзначає обмежену кількість сурдоперекладачів для користувачів державних послуг [3].

До прикладу, Урядовий контактний центр забезпечує можливість громадян України (у тому числі, які перебувають за кордоном) 3 порушеннями слуху за допомогою відеозв'язку звернутися на урядову «гарячу лінію» 1545 із пропозиціями (зауваженнями), заявами (клопотаннями), скаргами, адресованими органам виконавчої влади за допомогою Skype-зв'язку [18]. Стаття 19 Конвенції ООН зобов'язує державу-учасника сприяти у веденні самостійного способу життя людям 3 інвалідністю [4]. Незважаючи на те, що Україна ратифікувала вищезазначену Конвенцію, у державі все ж таки спостерігається систематичне порушення прав людей 3 інвалідністю, у тому числі осіб з порушенням слуху, на доступність інформації, що призводить до обмеження їх можливостей.

Лише в декількох областях у міських ЦНАПах запроваджено електронні сервіси «УТОГ», "ConnectPRO», що дають можливість одержати адміністративні послуги особам
3 порушенням слуху особисто. До прикладу 2019 р. в усіх офісах міста Львова запровадили перекладача жестової мови для нечуючих та слабочуючих людей. Запроваджено онлайн перекладача жестової мови для нечуючих осіб - через онлайн зв'язок відвідувач зможе якісно та швидко отримати: консультацію, подати звернення, подати документи на замовлення адміністративної послуги [19].

Напередодні Міжнародного дня глухих (27 вересня 2020 р.) аудит доступності послуг ЦНАП Святошинської РДА КМДА для осіб з порушеннями слуху перевіряли представники ВГОІ «УТОГ». Мета аудиту - ознайомлення з практикою безперешкодного надання послуг особам 3 порушенням слуху та поширення позитивного досвіду із забезпечення доступності адміністративних послуг для глухих людей та таких, що недочувають.

До слова, ЦНАП Святошинської РДА є найбільш відвідуваною особами з порушенням слуху установою та найбільш адаптованою для них. Адже комунікація без бар'єрів дозволяє надавати якісні державні послуги всім громадянам.

Першим кроком у наближенні послуг ЦНАП для жестомовних осіб стало освоєння базових навиків володіння жестовою мовою адміністраторами ЦНАП та скайп-зв'язок 3 перекладачем жестової мови територіальної організації УТОГ, який безпосередньо здійснює прямий і зворотній переклад жестовою мовою під час прийому заявника. Це дозволяє відвідувачам отримати необхідну консультацію та безперешкодно подати документи для замовлення адміністративної послуги.

Як показує практика, такий дистанційний зв'язок і надання послуг жестовою мовою є вкрай важливими. Тому інклюзивно-привітний сервіс для глухих людей і таких, що недочувають, і надалі буде одним із пріоритетних напрямів розвитку ЦНАП, 
щоб кожен відвідувач був почутим і гарантовано отримав послугу [8].

Колектив Деснянського ЦНАПу м. Києва також опановують основи української жестової мови. Колектив ЦНАПу співпрацює 3 Українським товариством глухих та продовжує навчання жестової мови у приміщенні Деснянської РДА. ЦНАП Печерської РДА також піклується, щоб послуги надавалися швидко та якісно, а кожен заявник почував себе комфортно: «нилюзивність - це принцип, який гарантує доступність державних сервісів для кожного громадянина» [7]. Адміністратори ЦНАПу здобули основні навички, необхідні для спілкування 3 людьми, які мають вади слуху та отримали першу подяку від заявника.

Щодо Миколаївської області, то у вересні 2019 року нами було направлено звернення з пропозиціями до Миколаївської обласної державної адміністрації та Миколаївської міської ради щодо впровадження електронного сервісу «ConnectPRO» у ЦНАПах Миколаївської області та міста Миколаєва зокрема. За результатами розгляду було встановлено, що органи місцевого самоврядування не мають передбачених місцевим бюджетом на 2019 рік коштів на запровадження у своїй роботі електронного cepвicy «ConnectPRO», але з огляду на актуальність проблемного питання розглядають можливість передбачити місцевими бюджетами на 2020 рік кошти цільового призначення на вказані потреби.

На жаль, позитивний досвід впровадження додатку «ConnectPRO» при наданні адміністративних послуг запроваджується в містах України дуже повільно. Таке становище пов'язане із відсутністю врегульованого механізму Законом України «Про адміністративні послуги», браком коштів на придбання оргтехніки в центри, бездіяльністю та байдужістю посадовців. Водночас варто зазначити, що останнім часом для осіб із порушенням слуху створюються належні умови в наданні послуг. Це свідчить про певні зрушення в напрямі забезпечення їх участі в житті суспільства.

У ході детального огляду національного законодавства щодо надання адміністративних послуг особам з порушенням слуху виявлено неврегульованість ї надання. Отже, такий стан справ призводить до унеможливлення отримання самостійно даних послуг. Вважаємо за потрібне запровадити додаток «ConnectPRO» або «Сервіс УТОГ» у всіх ЦНАПах України (в тому числі при використанні скап-зв'язку), зокрема Миколаівській області; проводити навчання жестової мови представниками УТОГ спеціалістам ЦНАП Миколаївської області; організувати курси жестової мови для населення при Департаменті соціального захисту населення Миколаївської облдержадміністрації.

Висновки. Отже, звернення осіб із порушенням слуху виступають основним засобом, за допомогою якого здійснюється реалізація прав людини i громадянина на вільне вираження своїх поглядів і переконань, вільне збирання, зберігання й поширення інформації, вільне об'єднання громадян для реалізації й захисту своїх прав, одержання інформації від органів державної влади та органів місцевого самоврядування, доступ до їнніх ресурсів, звернення до них, участь в управлінні $€$ найважливішими умовами й критеріями функціонування правової держави та чинниками розвитку громадянського суспільства [16, с. 16]. Нечуючі люди відчувають труднощі під час реалізації права на звернення, мовний бар'єр є найголовнішою перепоною, тому дистанційний зв'язок 3 використанням додатку «ConnectPRO» або «Сервісу УТОГ» і надання послуг жестовою мовою є вкрай важливими задля створення рівних можливостей для осіб із порушенням слуху.

Пропонується 3 метою удосконалення контрольної функції рад за діяльністю підзвітних їй органів і посадових осіб періодично, не 
менше одного разу на рік, заслуховувати питання забезпечення права на звернення на пленарному засіданні сесії ради. У м. Миколаєві з метою забезпечення реалізації та гарантування закріплених Конституцією України права на звернення до органів державної влади та місцевого самоврядування (ст. 40 Конституції України), права громадян на участь в управлінні державними справами, а також підвищення ефективності роботи органів місцевого самоврядування зі зверненнями громадян, ураховуючи необхідність об'єктивного, всебічного і вчасного розгляду звернень громадян, відповідно до вимог законодавства України розпорядженням Миколаївського міського голови від 26 лютого 2020 р. було посилено контроль щодо забезпечення реалізаціï та гарантування конституційного права громадян на звернення до органів місцевого самоврядування.

Перспективи подальших досліджень. Існує необхідність прискорити розгляд та прийняття проєкту Закону України «Про українську жестову мову» № 2340 від 29.10.2019 р. задля протидіï дискримінації за ознакою інвалідності та станом здоров'я, що буде спонукати все більший інтерес науковців до дослідження та популяризації даної проблематики.

У статті досліджено звернення осіб із порушенням слуху до органів публічної влади як основнии засіб реалізаціі права на інформаиію. Визначено проблеми надання адміністративних послуг під час звернення особам зі порушенням слуху на прикладі досвіду м. Миколаєва. Досліджено проблеми законодавчого регулювання та забезпечення конституційного права людини $i$ громадянина на звернення, оскільки нечуючі люди відчувають труднощі під час реалізаціi права на звернення, мовний бар'єр $\epsilon$ найголовнішою перепоною, тому дистанційний зв'язок із викорис- maнням додаmкy «ConnectPRO» або «Сервісу УТОГ» е вкрай важливими задля створення рівних можливостей для осіб з порушенням слуху.

Детально проаналізовано проект Закону «Про українську жестову мову» та запропоновано за потрібне запровадити використання в усіх органах державної влади та місцевого самоврядування додаmкy «ConnectPRO» або «Cервісу УТОГ» задля створення рівних можливостей для осіб з порушенням слуху. У ході детального огляду національного законодавства щодо надання адміністративних послуг особам зі порушенням слуху виявлено неврегульованість їх надання. Погоджуємось, щзо місиеві органи влади та органи місцевого самоврядування залишаються для осіб з інвалідністю інформаційно недоступними. Такий стан справ призводить до унеможливлення отримання самостійн даних послуг. Вважаємо за потрібне запровадити додаток «ConnectPRO» або «Сервіс УТОГ» у всіх ЦНАПах України (в тому числі під час використання скайп-зв'язку), зокрема в Миколаївській області; проводити навчання жестової мови представниками УТОГ спеціалістів ЦНАП Миколаівської області; організувати курси жестової мови для населення при Департаменті соціального захисту населення Миколаївської облдержадміністраиії.

Ключові слова: звернення, особи з порушенням слуху, жестомовні особи, адміністративні послуги, публічна служба, право на звернення, забезпечення прав і свобод людини і громадянина.

Kaplii O. APPEAL OF HEARING IMPAIRED PERSONS TO PUBLIC AUTHORITIES AS THE MAIN MEANS OF EXERCISING THE RIGHT TO INFORMATION

The article examines the appeal of persons with hearing impairment 
to public authorities as the main means of exercising the right to information. Problems of rendering of administrative services during the address to persons with hearing impairment on an example of experience of Nikolaev are defined. The problems of legislative regulation and ensuring the constitutional right of a person and a citizen to appeal have been studied, as deaf people have difficulties in exercising the right to appeal, the language barrier is the main obstacle, so remote communication using the application "ConnectPRO" or "UTOG Service" are crucial to creating equal opportunities for people with hearing impairments.

The draft Law "On Ukrainian Sign Language" was analyzed in detail and it was proposed to introduce the use of the "ConnectPRO" or "UTOG Service" application in all state and local government bodies in order to create equal opportunities for people with hearing impairments. A detailed review of national legislation on the provision of administrative services to persons with hearing impairments revealed irregularities in their provision. We agree that local authorities and local governments remain inaccessible to persons with disabilities. This state of affairs makes it impossible to obtain these services on their own. We consider it necessary to introduce the application "ConnectPRO" or "UTOG Service" in all TSNAPs of Ukraine (including when using Skype communication), in particular the Nikolaev area; to carry out training of sign language by representatives of UTOG to specialists of TSNAP of the Nikolaev area; to organize courses of sign language for the population at Department of social protection of the population of the Nikolaev regional state administration.

Key words: appeals, persons with hearing impairment, sign language, administrative services, public service, the right to appeal, ensuring human and civil rights and freedoms.

\section{Література}

1. Аналітична довідка за результатами проведеного Держкомтелерадіо моніторингу інформаційного наповнення офіційних веб-сайтів органів виконавчої влади у першому півріччі 2020 року. URL : http://comin.kmu.gov.ua/control/ uk/publish / article?art_id $=167745 \&$ cat_ $i d=112507$

2. Включення $i$ рівність. Моніторинг включення стандартів Конвенції ООН про права осіб з інвалідністю до Національної стратегії у сфері прав людини та інших довгострокових рішень в Україні (Звіт громадських об'єднань людей з інвалідністю), 2020. URL https: / / naiu.org.ua/wp-content / uploads/2020/03/NAIU-Report.pdf.

3. Заключительные замечания по первоначальному докладу Украины. URL: https: / / documents-dds-ny.un.org / doc/ UNDOC/GEN/G15/226/51/PDF/ G1522651.pdf?OpenElement.

4. Конвенція про права осіб з інвалідністю від 13.12 .2006 р. / База даних «Законодавство України. URL: https: / / zakon.rada.gov.ua/laws / show/995_g71\#Text.

5. Конституція України: прийнята на п’ятій сесії Верховної Ради України 28 червня 1996 р. Відомості Верховної Ради України. 1996. № 30. Cm. 141

6. Лист Міністерства ичифрової трансформації від 23.01.2020 року № 1/10-310-2020.

7. Почути кожного - колектив Деснянського ЦНАПу опановують основи української жестової мови. URL https: / / wrw.facebook.com / 560727253987892 / videos / 505844506646408 .

8. Почути кожного: напередодні Міжнародного дня глухих у ЦНАП Святошинської РДА ділились досвідом інклюзивно-привітного сервісу для глухих людей та таких, що недочувають URL : https://svyat.kyivcity.gov.ua/ news / 37408.html? PrintVersion.

9. Пояснювальна записка до проекту Закону «Про українську жестову мову» від 29 жовтня 2019 р. №2340 / Офіційний портал Верховної Ради України. URL : http://w1.c1.rada.gov.ua/pls / zweb2 / webproc4_1?pf3511=67223. 


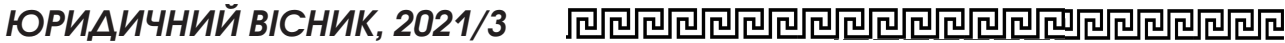

10. Проадміністративніпослуги:Закон України від 6 вересня 2012 року № 5203VI / База даних «Законодавство України». URL : https: / / zakon.rada.gov.ua / laws / show/5203-17\#Text.

11.Про внесення змін до деяких постанов Кабінету Міністрів України щодо функиіонування офіційних веб-сайтів органів виконавчої влади : Постанова Кабінету Міністрів України віо 12 червня 2019 року № 493 / База даних «Законодавство України». URL : https: / / zakon.rada.gov.ua / laws / show / 493-2019-\% DO \% BF.

12. Про забезпечення функціонування української мови як державної 25 квітня 2019 року № 2704-VIII / База даних «Законодавство України». URL : https://zakon.rada.gov.ua/laws / show/2704-19\#Text.

13. Про звернення громадян : Закон України від 2 жовтня 1996 р. №393/96ВР. Відомості Верховної Ради України. 1996 p. № 47. Cm. 257.

14. Про порядок денний n'ятої сесії Верховної Ради України дев'ятого скликання: Постанова Верховної Ради України від 2 лютого 2021р. №1164-IX / База даних «Законодавство України». URL : https: / / zakon.rada.gov.ua/laws / show / 11 6420 ? find $=1$ \& text $=\%$ D0\% B6\% D0\% B5\% D $1 \% 81 \%$ D1\% $82 \%$ D0\% BE\% D0\% B2\#w1_1.

15. Проект Закону України «Про українську жестову мову» від
29 жовтня 2019 р. №2340 / Офіційний портал Верховної Ради України. URL : http://w1.c1.rada.gov.ua/pls / zweb2 / webproc4_2?pf3516=2340\&skl=10.

16. Соболь В.А. Звернення громадян як механізм взаємодї держави та суспільства : автореф. дис. на здобуття наук. ступеня канд. наук з держ. упр. : спеи. 25.00.02. Київ, 2014. 23 c.

17. Соиька А.М. Правовий статус жестової мови в Україні. Науковий вісник Херсонського державного університету. 2017. T. 2. Bun. 3. m. 2. C. 61-63

18. Урядовий контактний центр приймає та реєструє звернення до органів виконавчої влади від осіб з порушенням слуху, використовуючи жестову мову. URL : https://ukc.gov.ua/uryadovyjkontaktnyj-tsentr-pryimaye-ta-reyestruyezvernennya-do-organiv-vykonavchoyivlady-vid-osib-z-porushennyam-sluhuvykorystovuyuchy-zhestovu-movu/.

19. Усі Центри надання адміністративних послуг Львова - доступні для людей з вадами слуху ma зору. URL : https: / / utog.org / pro-gluxix/usi-czentrinadannja-administrativnix-poslug-lvovadostupni-dlja-lyudej-z-vadami-sluxu-tazoru.

20. Цивільний кодекс України від 16 січня 2003 року № 435-IV / База даних «Законодавство України». URL : https: / / zakon.rada.gov.ua/laws / show /435-15/conv\#n1720. 